\title{
Participatory Development, Complicity and Desire
}

\section{ILAN KAPOOR}

ABSTRACT This article is an attempt at rethinking participatory development $(P D)$ in terms of empire, undertaking a postcolonial and psychoanalytic reading. Postcolonialism helps point out that our discursive constructions of the Third World say more about us than the Third World; while psychoanalysis helps uncover the desires we invest in the Other. Thus, to the question, 'why do neo-imperial and inegalitarian relationships pervade PD?', the article answers, 'because even as $P D$ promotes the Other's empowerment, it hinges crucially on our complicity and desire'; and 'because disavowing such complicity and desire is a technology of power'. The argument, in other words, is that complicity and desire are written into PD, making it prone to an exclusionary, Western-centric and inegalitarian politics. The article concludes with possibilities for confronting our complicities and desires through PD's radicalisation.

At a time when imperialism looks naked and pervasive, when 'freedom' and 'democracy' are all but forced on people (eg in Iraq), any North-to-South exchange appears particularly suspicious. Thus, thanks at least in part to the growing influence of the Western-dominated Bretton Woods institutions, the field of international development struggles harder and harder to escape its reputation as a Trojan horse. And now, so does one of its newest offspringparticipatory development (PD) - and this in spite of the latter's 'noble' goals.

PD ostensibly implies discarding mainstream development's neocolonial tendencies, Western-centric values and centralised decision-making processes. It stands instead for a more inclusive and 'bottom-up' politics, which takes two dominant institutional forms: 1) Participatory Rural Appraisal (PRA), which aims at promoting local community 'empowerment'; and 2) country 'ownership' of development programmes, where the state and/or international development agency seeks civil society involvement for policy development and agenda setting. ${ }^{1}$ In one form or the other, PD has become development's new orthodoxy, so much so that you would be hard-pressed to find any NGO, donor agency or development institution that has not integrated it into programming.

But of late PD has faced notable scrutiny and criticism. Critics point out that, far from being inclusive and bottom-up, it reconfigures power and value 
systems which may end up being exclusionary, if not tyrannical (Mosse, 1994; Cooke \& Kothari, 2001; Kapoor, 2002a). It is shown to be gender-biased, frequently ignoring and reinforcing patriarchal structures (Parpart, 2000). And it seen as a 'liberal populist' approach to development that fails to address either class inequalities or the negative impacts of macrosocioeconomic structures (Mohan \& Stokke, 2000).

I would like, in this article, to include and extend the above criticisms by carrying out a postcolonial and psychoanalytic reading of PD. Postcolonialism helps point out that our discursive constructions of the Third World say more about us than the Third World; while psychoanalysis helps uncover the desires we invest in the Other. Thus, to the question, "why do neoimperial and inegalitarian relationships pervade PD?', I want to answer, 'because even as it promotes the Other's empowerment, it hinges crucially on our complicity and desire'; and 'because disavowing such complicity and desire is a technology of power'. In other words, I want to argue that complicity and desire are written into PD, making it prone to an exclusionary, Western-centric and inegalitarian politics.

I write 'our' in an effort at self-implication: it seems to me that, whether we are critics or advocates of PD, we are implicated in it. As development workers and researchers, as intellectuals and academics, we may make (at least a part of) our careers off it. As Westerners, some of our sociocultural values and practices may inform PD (as we shall see below). As members of Western(ised) elites participating in the global capitalist economy, we may be direct or indirect contributors (as taxpayers, consumers, voters) to those national or transnational institutions that 'invest' in PD. True, there are different degrees of contamination here; but my point is that not owning up to the range of these complicities ensures the reproduction of inequality and empire.

\section{Complicity and desire}

To begin the task of excavating complicity and desire from the depths of PD, I take my cue from Edward Said, Gayatri Spivak and Slavoj Žižek. Said's significant contribution, of course, is showing the Orient to be a discursive construct (Said, 1978). He points out how Orientalism (ie the West's political-intellectual representation of the Third World) is integral to imperialism, serving both to subordinate the Third World and rationalise Western imperial rule. His implication is that Orientalism, while ostensibly staging the (Third World) Other, actually reveals the West: 'Indeed, my real argument is that Orientalism is and does not simply represent-a considerable dimension of modern political-intellectual culture, and as such has less to do with the Orient than it does with "our" world' (1978: 12).

Much of Spivak's work is an extension of this insight. She cautions that, in speaking about the Other, we often disavow our own role in the representational process, as though we are transparent and neutral relays (Spivak, 1988). Like Said, she thus believes that it is important that we turn our anthropological gaze upon ourselves before we investigate the Other. Her insinuation for us (as academics, researchers or development workers) is that 
our representations about, or on behalf of, the Third World are a function of our geopolitical and institutional positioning (Kapoor, 2004b). Because we are part of organisations that have their own class, gendered, cultural and/or organisational demands, we cannot pretend to purity or objectivity in our dealings with the Third World.

Žižek, in my view, provides a depth psychology to the contaminations and complicities that Said and Spivak alert us to. Relying on Lacanian psychoanalytic theory, his argument proceeds something like this: 'reality' goes hand in hand with, but is opposed to, the 'Real' (Žižek, 1989: 69; 1999: 74). Reality is what we (mistakenly) take to be wholeness or harmony, while the Real denotes the impossibility of wholeness, a fundamental lack that troubles any attempt at closure and consistency. For Žižek, from the moment we enter into the world of language, reality is where we escape to avoid the Real $(1989: 45,47)$. We desire and enjoy fullness (eg the perfect car, pure love, an ideal democracy), and find it difficult to come to terms with incompleteness (that is written into the very structure of language), and so we construct a fantasy world. Desire thus involves the misrecognition of fullness, and fantasy is "the support that gives consistency to what we call "reality" '(1989: 44).

While fantasy is an individualised or internalised psychic phenomenon, ideology interpellates us at the level of the social, from the outside. Like fantasy, it is a framework that forecloses the Real in order to make reality smooth and consistent. But Žižek is adamant that ideology is not a mask or veil covering the 'real' situation, a reality behind reality: it is 'not simply a "false consciousness", an illusory representation of reality, it is rather this reality itself which is already to be conceived as "ideological" ' (1989: 21). In this sense, for Žižek, ideology is externalised and materialised: it is built into our sociopolitical practices and institutions.

But if it surrounds us and interpellates us, how do we go about distancing ourselves from it, critiquing it? Not through the development of some superconsciousness, since, as just pointed out, there is no 'higher' ground from which to distinguish 'true' from 'false' reality. And not through some sort of postmodern ironic distance, in which we admit we know better than to do something (but nevertheless go ahead and do it): the TV viewer, for example, may mock and rail against TV advertisements, aware that they are commercial manipulations; but the point is that $\mathrm{s} /$ he still watches them, and does so with some delight. Irony or cynicism for Žižek, far from being critical, are built into ideology, underlining both how insidiously pervasive ideology is and how psychically enjoyable it can be (1989: 28, 33). No, ideology critique, according to him, can only be undertaken from within ideology itself, by being intimately alert to its machinations. And this means tracking and identifying ideology's Real-its slips, disavowals, contradictions, ambiguities.

What Žižek helps reveal, then, are the psychoanalytic dimensions of our complicities. He points up the psychical-ideological work that goes into desiring reality and disavowing the Real or, in our case, desiring to empower the Other and overlooking our complicity. And so, drawing on these insights, I want to show PD to be ideological. As we shall see, it is promoted as 
benevolent, but forecloses various complicities and desires. It is championed and propagated by development institutions, which nonetheless seek to obscure their own participation in participation. It supposedly puts local Third World communities at the centre of development, but actually centres on First World and/or elite institutional and geopolitical interests. The task ahead, then, is to track these complicities and desires, and to scrutinise their accompanying slips, disavowals, contradictions, ambiguities.

\section{Tracking complicity and desire}

This section examines complicity and desire as they manifest themselves in the assumptions, values and goals of PD. We begin by dissecting PD's image of magnanimity, move on to investigating the unconscious desires it has written into it, and end with problematising its objective of reaching consensus.

\section{Narcissistic samaritanism}

PD appears to be pulled in two directions at once: being promoted as benevolent, while professing neutrality in order to 'empower the Other'. As to the first of these, there is an unmistakable self-righteousness that pervades PD. Partly, this is the inheritance of the field of development, in which the mentality of the 'burden of the fittest' prevails: not only is pride taken in the philanthropic idea of 'us' helping 'them', but also in the assumption that we (elites and professionals) know better than they (impoverished Third World communities). Perhaps some of this self-congratulatory benevolence has faded lately, in the wake of harsh condemnation, notably of the socioenvironmental costs of IMF/World Bank-led structural adjustment programmes. But the emergence of PD appears to have neutralised some of these criticisms and saved the day. Armed with its message of enabling local community participation, $\mathrm{PD}$ has become a kind of development with a clear conscience. Its 'empowerment' dimension, in fact, gives it an almost sublime character, so that it has come to be associated with a series of seemingly incontestable maxims: $\mathrm{PD}$ is naturally progressive, community participation is inherently good, championing PD is blameless and honourable.

Added to this is a certain religious dimension, particularly noticeable in PRA. It is evident, first, in the figure of the PRA 'facilitator', who plays the crucial role of the change catalyst. Robert Chambers, charismatic enthusiast and promoter of PRA, stands as model here. Affable and earnest, he cuts a preacher-like personage (Henkel \& Stirrat, 2001: 175). His writings are strewn with moral exhortations, encouraging the PRA facilitator to shed hierarchical thinking and Westernised ways (1994: 1256). Like the ascetic or monk who has overcome worldly attachments, the facilitator is expected to develop astringent powers (more on this below) and, as Paul Francis puts it, enact 'an exorcism, of sorts, of phantoms of "conventional" development practice' (Francis, 2001: 80). But PRA's religiosity is also evident in the way 
it envisions social change. PRA-led community discussions can become ecstatic experiences, causing socioeconomic elites (or 'uppers'), in particular, to re-think their privileges and undergo tremendous personal transformation: it means that those who are uppers and powerful step down, disempower themselves, and empower others...It implies that uppers have to give up something and make themselves vulnerable' (Chambers, 1997: 234). Seen in this light, then, the PRA exercise becomes a (Christian evangelical) religious ceremony, in which the facilitator-as-priest presides, privilege and power are purged, and the community is reborn.

Running counter (or so it appears) to the construction of a benevolent and quasi-religious aura around PRA, however, is an attempt at self-effacement. The logic here is that outside interference and imposition must be minimised in order to facilitate civil society 'ownership' of programmes or enable community empowerment. The onus, once again, is on the convenor or facilitator to be neutral and objective so as to allow the community agenda to emerge authentically. Thus, PRA repeatedly underlines the need for 'handing over the stick', urging in its facilitators the cultivation of such personal behaviour traits as transparency, honesty, humility, respect and patience (Chambers, 1994: 1253, 1256).

But how is one to reconcile this self-effacement with the earlier selfregarding benevolence? The answer, it seems to me, lies in the power relationships set up in PD's community workshops or forums. The convenor or facilitator may well portray him/herself as a neutral and fair arbiter, but the fact is that $s /$ he manages the proceedings almost every step of the way: deciding on the need for, and purpose of, the meeting; selecting whom to include/exclude on the invitation list; making up the agenda; choosing which participants speak, on what topic and for how long; and/or shaping the form and use of the meeting outputs. There are no 'objective', or indeed intersubjective, rules or procedures governing meeting goals, logistics or discussions. Power is tilted decidedly in favour of the convenor, and, while it may well be used accountably and democratically (as Chambers hopes for), it can just as easily be abused.

Either way though, given the convenor's substantial discretionary powers, any attempt at self-effacement, far from running counter to self-aggrandisement, is rather another strategy for it. Pretending to step down from power and privilege, even as one exercises them as master of ceremony, is a reinforcement, not a diminishment, of such power and privilege. Humility, patience, respect, etc, may be the public expression of PD's guilty conscience ('I'm a bit ashamed of being in charge of your "empowerment"... and isn't it nice of me to acknowledge it?'); but these may also be acts of self-glorification and -gratification ('it doesn't really matter whether or not people are "empowered", as long as I come off looking good!'). The result in both cases is that PD centres, not on the Other, but on the $I$.

PD fits well, then, the Zižekian definition of ideology as a 'lie which pretends to be taken seriously' (1989: 30). It appears immaculate, founded as it is on enabling unadulterated participation; upon such purity does its reputation as noble and progressive rest. Yet it hinges on a fundamental 
underside-the enabler's complicity. Its ingeniousness rests on successfully negotiating this slipperiness. It creates a 'feel good' community experience, but elides the behind-the-scenes stage management. It promotes the sharing of power, but manages to centralise power by personalising and mythologising the role of the facilitator. The latter feature is perhaps what makes PD so desirable to the development establishment - its narcissistic pleasurability: not only does one get to stage the empowerment process, but one also gets to be the centre of attention, deriving enjoyment and praise for it.

\section{Transference}

I would like to track another, related form of complicity by suggesting that PD is, to a degree, the result of psychical transference. Transference is the displacement of unresolved conflicts onto a substitute object, whereby, for example, the lover, analyst or friend is a stand-in for the parent toward whom one feels aggression. PD, I want to suggest accordingly, is the consequence of transference onto Third World communities of the perceived inadequacies of our own liberal democratic political systems.

Several analysts (eg Habermas, 1976; Kothari, 1988; Mouffe, 2000) have highlighted the rising 'democratic deficit' within mainstream political institutions in the First and Third Worlds. Public apathy and low voter turn out, they contend, are the product of increasingly distant and exclusionary party politics. The emergence of various fundamentalisms (religious, ethnic, nationalist), as well as grassroots public protests and social movements, are responses to the unaccountability and corruptibility of the state and market. There is thus a wave of political dissatisfaction and a demand for a more participatory democracy that has entered our liberal democratic culture, and in turn, the consciousness of the development intelligentsia.

Of course, such frustrations and demands are channelled in various ways (eg through public protest), but some of them may be psychically transferred through our development work. PD then becomes a vehicle for us to try and resolve real or imagined liberal democratic deficiencies. (Such an argument, to my mind, does not appear to be a stretch: after all, a good deal of postWorld War II aid and development was aimed at containing the Soviet 'threat' to meet Western foreign policy objectives, and at spreading 'free market' policies to help in the much-needed opening up of Third World markets for multinational capital. Moreover, a sizeable portion of development transfers today continues to be 'tied', and to this extent, helps resolve several economic bottlenecks. Western food aid, for example, is often a subsidy to Western farmers and a way of disposing of their food surpluses (eg of wheat or rice); and the sizable US military aid budget helps prop up the country's military-industrial complex. The transference of which I speak is thus no different in its channelling of, as it were, surplus idealism and disgruntlement, so helping to address political bottlenecks.)

A sure sign of this transference is that, when it comes to PD, we ask more of marginalised Third World communities than we do of ourselves. All things considered, how many of our own Western social institutions and 
programmes (eg employment, gender or poverty-related programmes) are participatory? Very few, if any. The implication is that we hold the 'beneficiaries' of PD to a higher standard or ideal. As a consequence, Third World communities may well be a dumping ground or test site for idealised forms of participation.

Žižek helps tease out a further dimension of such transference via his discussion on 'canned laughter' (ie simulated audience laughter, usually on television comedy programmes). For him, the significance of canned laughter lies not in reminding us when to laugh, but in the fact that

the Other-embodied in the television set-is relieving us even of our duty to laugh - is laughing instead of us. So even if, tired from a hard day's stupid work, all evening we did nothing but gaze drowsily into the television screen, we can say afterwards that objectively, through the medium of the other, we had a really good time (1989: 35 ).

Seen in this light, PD is a kind of canned laughter: it helps us work through our political idealism and discontent, relieving us from participating over here' and enabling us to partake vicariously through the other's participation 'over there'. We manage the process (and get the glory), they participate (as directed by us), and at the end of the programme, we come away feeling satiated as spectator-participants.

Žižek interprets this phenomenon as symptomatic of 'commodity fetishism' under late capitalism: human relationships take on the form of relations between things, so that we increasingly interact with one another in abstract, vicarious and alienated ways (1989: $34-35$ ). The irony, in this case, is the prospect that commodity fetishism has colonised even participation, an activity meant precisely to overcome alienated human relations through inter-subjective dialogue.

\section{The fantasy of consensus}

One of the main objectives of PD is arriving at a consensus. Once the key community 'stakeholders' are gathered, relevant information is collected, and people have had their say, a collective decision is reached. The development programming that ensues is thus taken to be not prescriptive but reflective of community interests and needs. But to the extent that consensus is an attempt at making development smooth and complete, it is a fantasy (in the Žižekian sense discussed earlier). To the extent that it is used to seek definitive decisions, thereby avoiding the risks and messiness (ie the Real) inherent in participation, it is the product of self-delusion. Zižek avers, as a result, that establishing " "real" democracy [or participation] necessarily brings about its opposite' (1989: 5), and Chantal Mouffe speaks of consensus as the 'elimination of pluralism from the public sphere' (2000: 49). ${ }^{2}$

Indeed, the quality of the consensus and the power relations involved in reaching it are crucial. One danger is that decisions are made on the basis of inadequate participation, for example when beneficiaries are consulted after 
the programming design and goals have already been set; or when agreement is justified through majority vote and frequent community meetings, rather than meaningful deliberation (ie open dissemination of information, airing of dissent and debate, inclusion of minority views). In the meeting space itself, moreover, there may be several micro-power processes at play. For instance, rhetorical devices-polemical or sensationalist arguments, technical or esoteric language, misrepresentation or over-representation of evidence, loud or aggressive speech, monopolisation of air time by a participant - can unduly influence opinion or silence and intimidate participants. While sometimes overt, these devices can be subtle, too, as when the meeting convenor invites technical or scientific 'experts' to speak to (ie persuade) community members.

The very condition of having to seek a consensus may also be a problem. When consensus-based decisions are single, as they most often are, they overlook or suppress community differences and tensions. Frequently, they ignore precisely those issues that are most difficult to address-class inequality, patriarchy, racism (Mohan \& Stokke, 2000; Mosse, 2001: 22; Kapoor, 2004b: 637). Rather than confront these messy problems, they leave them unspoken or unresolved. The result is a simplified or distorted consensus. Thus, Kelsall \& Mercer (2003) show how a World Vision participatory community development project in Northern Tanzania ends up concentrating power in the hands of established elites (church elders and employees, village council members, rich farmers) to the exclusion of poorer farmers and women. Not only does decision making become monopolised by these elites, but so do project resources (access to funds and training, allocation of free cattle), thereby 'reproducing existing inequalities and perpetuating patterns of development which date from the colonial period if not earlier' (Kelsall \& Mercer, 2003: 302; cf Mosse, 1994: 508). The 'common good' becomes the expression of hegemonic privilege and subaltern loss.

My point is not to deny that decisions need to be made in PD. It is, rather, to warn against the fetishisation of consensus, that is to say, the desire to reach a single (and perfect) agreement at any cost. The tendency of consensus making is towards closure, and hence towards the privileging of some voices, and the simplification, suppression and exclusion of others. In the absence of objective or inter-subjective procedures governing participation (or perhaps even with them), ${ }^{3}$ this proclivity is ever-present. Averting or abetting it is once again the responsibility of the convenor. It is his/her benevolence or selfinterest that in large measure determines the quality of participation and the politics of consensus making.

\section{Complicity and desire institutionalised}

Complicity and desire are present not just in PD's values and goals; they are also integral to PD's institutional arrangements. This section tracks them in PD's packaging and branding, its disciplining mechanisms, and its neoliberal conditionalities. 


\section{The packaging and branding of participatory development}

When participation is incorporated into development programming, it is subjected to a plethora of organisational demands. It is made to conform, for example, to bureaucratic review and approval procedures, budgetary deadlines, and/or reporting requirements such as the collection of statistics (eg participation rates, frequency of meetings, gender breakdown of participants). It is thus gradually institutionalised, much as a hospital patient might be, after being admitted, tested, diagnosed and classified. It is also moulded to suit project needs, becoming a management 'tool' to help increase project sustainability and results. 'Toolkits' and 'modules' are produced for this purpose (eg Srinivasan \& Narayan, 1994). As a consequence, $\mathrm{PD}$ is transformed into package-discrete and manageable to suit the institutional culture, and modular to make it flexible and transferable to various project sizes, tasks and contexts.

In addition to PD's packaging is its institutional marketability. It has become one of development's latest trends, following on the heels of 'women in development' (in the 1980s), 'sustainable development' (in the early 1990s), and 'human rights' and 'governance' (in the mid-to-late 1990s), respectively. Such 'trendiness' is more than just incidental; it is surely deliberate. Just as product differentiation is a corporate strategy to ensure the reproduction of consumerism and capital, so each new trend safeguards development's renewal and marketability. The 'new' turns attention away from the 'old' (recurring problems, challenges), mobilises new energy and resources, and inaugurates a 'fresh' start; and so the development machine keeps turning.

But participation is more than just a trend; it is also an institutional brand. Its marketability and fashionability mean that $\mathrm{PD}$ is now de rigueur in the development community. It has acquired a certain cachet or, as I discussed earlier, a subliminal aura. David Mosse (2001: 23-24) explains, for example, how the Kribhco Indo-British Rainfed Farming Project has donned participation as a mark of respectability, in spite of the fact that decision making remains mostly top-down.

Participation's cachet acts in many ways like corporate 'lifestyle branding' (Klein, 2000). PD is made into a self-expressive lifestyle product: in the same way that to buy Starbucks is not just to buy coffee but to identify with 'community', or to wear Benetton is not simply to wear clothing, but to embrace 'multicultural diversity', so to institute PD is not simply to take on participation, but to enhance 'community empowerment', 'good government' or 'democracy' (presumably, a Western-style, wealthy democracy). Such branding brings instant recognition and respect, while enabling development institutions to build long-term trust and loyalty with their 'clients' (governments, communities, NGOs). And cultivating these long-term affective attachments is the best publicity development can't buy!

Packaging and branding are evidence of PD's institutional complicities. When it is managerialised and marketed, then what matters is not so much 
whether participation works or is well done, but how it can help protect and advance institutional authority (cf Ferguson, 1990). Consequently, far from being taken up for people's empowerment or democratic governance, PD is taken up, first and foremost, for institutional aggrandisement.

\section{Panopticism}

Panopticism refers to the phenomenon of self-policing (Foucault, 1984: 239). For instance, in contemporary societies surveillance has become increasingly pervasive (in the form of video surveillance, collection of social security or tax data, security assessments, etc), so that people, even if they do not like it, end up internalising it. This has important implications for $\mathrm{PD}$, since participation is public, and a public participatory space can be a panoptic one. Under the watchful eyes of the community, participants perform roles by playing to an audience, living up to an expectation, or acting out a socially sanctioned duty. Thus, for example, the village leader personifies the authority figure, the facilitator acts as the benevolent arbiter, the woman performs her prescribed gender role, the minority group accentuates its status as 'dependent' or 'victim', and the community as a whole plays at pleasing the project funder. PD's public and panoptic character mean that power relationships are reconfigured, affecting the way people interact, information is expressed and knowledge is exchanged.

The problem is that this reconfiguration of power does not happen in a vacuum; it happens in the context of already established community relations. As a result, unequal power relationships, far from disappearing, adjust to PD's new power/knowledge regime. David Mosse's work highlights this phenomenon with particular reference to PRA. He finds that what is taken to be 'local' knowledge or needs, for instance, can be a reflection of the preferences and biases, not of the community, but of the authority to which it is beholden (eg the donor, the state). Hence, adivasi villagers in Western India are found to prefer using eucalyptus as timber for housing; they do so, however, not because they have had prior experience with it or as a result of some 'indigenous knowledge', but because the local Forest Department favours it (Mosse, 2001: 20-21, 17). In another instance Mosse reports that some community members often shy away from giving their personal opinions at PRA gatherings, preferring instead to provide the 'official story'. Women participants, in particular, are liable to speak guardedly, or indeed to let their husbands speak for them, thereby responding to patriarchal and sociocultural taboos against speaking frankly in public (Mosse, 1994: 508, $514-515)$.

The realignment of relations occasioned by PD happens, then, in favour of the powers that be. Dominant groups soon develop an 'interest' in the new truth regime, adjusting and rearticulating their interests in accordance with it. Government officials may discover it helps monitor community activities; husbands and fathers may see it as a way of keeping tabs on their wives/ daughters; elites may take it as an opportunity to manage dissent; the PD convenor may find in it a way of manufacturing consent; and everyone may 
delight in its production of gossip and rumour about friends and neighbours. Eventually, following Foucault's logic, each community member will end up self-disciplining, that is, internalising the socioeconomic, cultural and patriarchal dos and don'ts. And before long, what were once select dos and don'ts - reflective of elite/institutional complicities - are taken for granted: they become naturalised, passing off as 'consensus', 'community will' or 'traditional knowledge'.

I cannot help but follow such panopticism to its ultimate conclusion: a Nineteen Eighty Four scenario. The seeds of it lie in the institutionalisation of PD. Indeed, most PD projects envisage their own periodic monitoring and evaluation (Makuwira, 2004: 8). The idea is to ensure that project resources are being used efficiently, and that the project is sustainable and effective. Yet, under a panoptic lens, such monitoring and evaluation translate into the totalisation of panopticism-the monitoring of monitoring and the disciplining of discipline! Here, it is not just about people watching people anymore, but about putting in place institutional mechanisms that ensure that everyone is watching everyone. Now this may well be a far-fetched, nightmarish scenario, but as Žižek is quick to remind us, excess seems unreal and unthinkable to us, outwardly because we cannot integrate it with our own experience, yet psychoanalytically because we are in fact intimately familiar with it (2002: 19). Calling it a 'nightmare' is our way of avoiding the Real, which in this case is about disavowing our socio-institutional complicities (ie our institutional panoptic and disciplinary tendencies, our voyeuristic desires) so that we/ PD can appear pristine and pure. Thus Žižek says about 9/11 that the USA 'got what it fantasized about': a Hollywood disaster film - the ultimate American desire-fantasy - came true (2002:1516). And while characterising $9 / 11$ as 'unreal' was a way of coping, it was also a way of overlooking US state-abetted imperial activities around the world.

\section{Conditionality}

Two decades ago participation was anathema to such transnational institutions as the World Bank and IMF. Now, in the aftermath of acerbic criticism about the top-down and exclusionary character of their structural adjustment programmes, not only do they embrace participation with panache-in itself a suspicious development--but they also make it a condition of assistance. Thus, for the Heavily Indebted Poor Countries (HIPC) especially, debt relief is contingent upon a poverty reduction strategy (PRS), which in turn requires local 'ownership' (World Bank, 2003; 2000: 253). Recipient governments are expected to form 'partnerships' with civil society organisations when putting in place their PRS.

A case in point is present-day Tanzania. To access funds through the HIPC initiative, it has agreed to comply with various adjustment policies (ie privatisation of 'inefficient' parastatals, public sector reforms, establishment of a pro-business investment climate) and form partnerships with NGOs for its PRS. But as Claire Mercer (2003) discovers, such partnerships are the result of a top-down government decision-making process that tends to 
privilege elite NGOS (ie professionally run, and usually donor-funded), at the expense of weaker, community organisations. Moreover, civil society participation amounts to little more than consultation, with governmentinitiated community forums as veiled attempts to convince participants of the wisdom of already agreed-upon strategies. As a consequence, Mercer writes, the 'increased profile of NGOs in policy-making engages them and other actors in a performance of partnership... which serves to legitimise continued (structural) adjustment...partnership has become a synonym for consensus on adjustment' (2003: 743, 751). Similar situations have played out in Rwanda and Bolivia (Renard \& Molenaers, 2003a, 2003b), with participation serving, in the former case especially, as a cover for what is otherwise an undemocratic, if not authoritarian, state.

The erstwhile top-down structural adjustment regime is thus reconfigured to the specifications of the new PD regime. Championing PD and making it a condition of assistance accomplishes several tasks in one fell swoop: participation becomes a disciplinary mechanism for the World Bank/IMF to hold the poorest Third World states 'to account' (in both the financial and discursive senses of that expression) and, in turn, for these states to keep civil society organisations in check; and participation helps advance neoliberalism, promoting 'partnerships' to co-opt Third World states and (elite) NGOs into the structural adjustment programme.

\section{Broader implications}

My point in tracking the above complicities and desires in PD is not to argue that they show up all of the time and in every aspect of programming; it is to suggest instead that they are liable to (and do) show up somewhere and at least part of the time because they are integral to PD. The propagation of PD depends fundamentally on a propagator or convenor, who in the current geopolitical conjuncture tends to be $u s$ as members of elites and institutions in both the North and South. It is because of such inescapable complicity that personal and institutional benevolence in PD, while outwardly otherregarding, is deeply invested in self-interest (geopolitical, cultural, organisational, economic) and desire (narcissism, pleasurability, self-aggrandisement, purity, voyeurism, manageability, control).

But PD's propagation is premised on overlooking these contaminations (ie the Real), and to this extent it is an ideology, in the Žižekian meaning of the term discussed earlier. PD as ideology is attractive and pleasurably desirable (in indulging our self-centredness). It is marketed and branded as wholesome and unblemished. But, even as it papers over its 'dirty secrets', what is notable about its ideological and misrecognising force is the ability to appear open, inclusive and transparent: 'The central paradox...is that the very process of production, the laying bare of its mechanism, functions as a fetish which conceals the crucial dimension of [its] form' (Žižek, 1997: 102). ${ }^{4}$

Three implications follow. First, the disavowal of complicity and desire (ie the construction of PD as ideology) is a technology of power, as a result of which participation can easily turn into its opposite-coercion, exclusion, 
panopticism, disciplinarity. Here, 'participation as empowerment' morphs into 'participation as power'. PD may appear pure and unmediated but, for this very reason, as we have seen, it is often deployed to wield authority, helping to maintain and further elite or institutional hegemony. Flashing PD as a badge, or romanticising our involvement in it, will tend to be similarly dangerous: innocently or benevolently claiming that one is helping a Third World community become participatory is not just self-aggrandising, but also risks perpetuating elite, panoptic or institutional power, all at the expense of the Third Word community. (This of course conjures up the triumphalist Bush/Blair claim of bringing 'freedom and democracy' to Iraq.)

A second implication is that $\mathrm{PD}$ is a vehicle for various types of empire building - institutional, geopolitical, socioeconomic, cultural, personal. ${ }^{5}$ One such instance, as underlined earlier, is the branding of PD to help widen institutional spheres of influence, while another is the World Bank/IMF construction of $\mathrm{PD}$ as conditionality, through which participation becomes a 'euphemism for [global] neo-liberal capitalism' (Roy, 2004: 56). ${ }^{6}$ In either case, it is no wonder that PD is a vehicle for empire: in this era of mediatisation, when image and spin matter so much, the construction of PD (or indeed of 'freedom' and 'democracy') as 'benevolent' and 'good' is an ideal cover.

Note that to make such an argument is not to maintain that power is conspiratorial $(\mathrm{PD}=$ empire building $=$ Western conspiracy). On the contrary, it is to agree with Foucault in suggesting that power circulates, so that institutional and social complicities and desires adjust, and are reconfigured, to PD's new power/knowledge regime. Thus, as mentioned earlier, consensus building can align with elite/institutional interests, and community gatherings can end up helping state monitoring of local communities. Now it is true that, in the current global context, many of these complicities and desires are Western/Westernised, reflecting Western economic, geopolitical and cultural hegemonies. But they are not exclusively so (as I have tried to underline); they also reflect local hegemonies (class, patriarchal, institutional).

Moreover, it is because power circulates that we, Western(ised) elites and intellectuals, are implicated in empire. For example, as the earlier discussion on 'transference' emphasised, our development work is psychically and politically conditioned, so that we, too, develop, amend and transfer our interests and desires in accordance with PD's knowledge/power regime. This is why it is too easy and convenient to blame contemporary empire building on transnational corporations or the Bush/Blair administrations alone; the latter may well be more powerfully complicitous, but this is no reason for us to claim innocence or neutrality. Empire building, in this sense, may well be a broadly cultural sign of the times, implicating the 'noble' as much as the 'ignoble', 'participation' as much as 'trade', 'citizens' as much as 'leaders'. And this is also why dismantling empire, if it is to happen, must take place at so many levels simultaneously (personal-structural, local-global, socialinstitutional, North-South, etc), a point I shall take up further below.

A final implication is that PD perpetuates the treatment of the Third World as object and resource. If empowerment centres not on the Other but on our 
own desire to be seen as benevolent, then Third World communities are in effect regarded as pawns. ${ }^{7}$ If participation is a conduit for transference of our politico-cultural ideals and frustrations, then the Third World becomes a disposal site, in the way that it already acts as a dumping ground for toxic waste or hazardous multinational corporate products (eg milk substitutes, contraceptive implants). And if PD enables the collection of information or 'field data' for our research and disciplinary/managerial needs, then the Third World is made into both resource and laboratory. Spivak argues, in this regard, that the Third World produces 'the wealth and the possibility of the cultural self-representation of the "First World" " (1990: 96).

\section{Conclusion: what to do?}

My point is not that everything is bad, but that everything is dangerous, which is not exactly the same as bad. If everything is dangerous, then we always have something to do. So my position leads not to apathy but to a hyper- and pessimistic activism (Foucault, 1984: 343)

We can save democracy only by taking into account its own impossibility. (Žižek, 1989: 6, emphasis in the original)

My point is not that PD is bad, but that it is dangerous. The reason is that it is fundamentally adulterated, so that along with its medicine comes its poison (cf Parfitt, 2004: 554-555). Yet this is not grounds to discard it (lest its poison return in even more potent forms), but rather to 'confront the Real' (Žižek, 1989: 48, 63), which in our case is about recognising and coming to terms with our complicities and desires. In the preceding analysis, I have attempted to identify this Real by tracking its various forms; in the four possibilities that follow, I will try to come to terms with it by arguing for the broadening, deepening and radicalisation of participation.

\section{Publicising complicity and desire}

The most obvious implication from the above analysis is the need to admit to our complicities and desires, that is, to make them open to scrutiny and discussion. Unilaterally moralising about the correct behaviour of the facilitator ( $\dot{a}$ la Chambers) is, as we have seen, a recipe for self-promotion and benevolent paternalism. In contradistinction, politicising and publicising the prejudices and prerogatives of the facilitator should help de-centre and democratise power relationships. It will entail, for the facilitator, tempering and contextualising one's claims and commitments, and for the participants, lowering one's hopes and expectations. It will also entail subjecting the PD meeting's rules and procedures, not just its contents, to public deliberation.

Of course, the risk of airing our complicities and desires is that participants may not want to have anything to do with us (why would they, if we were really to admit to empire building?). But, though a failure for us, such an 
outcome would in many ways be a success for them: saying 'no' would move them from object to subject of development; it would be a meaningful sign of their 'empowerment'.

Yet many pitfalls remain even here. The onus for PD's politicisation continues to lie with us as facilitators/convenors; it remains dependent on our continued 'generosity' or cunning desire. Moreover, the likelihood is small that development organisations will be open to PD's radical democratisation or willing to recognise failure as success.

\section{Extending participation to the economy and development decision making}

There are two glaring blind spots in the deployment of PD: its integration into the economy and its application to the decision-making processes of the very development institutions that deploy it.

To be sure, proponents of participation appear only too happy to initiate projects in such areas as education or urban planning, but reluctant to do so in more politically difficult areas such as, say, manufacturing. When the economy is broached, PD is used, as we have seen, to push neoliberal capitalism, ignoring questions of distribution or inequality. Politicising the economy is thus a taboo. Žižek, in fact, sees it as today's global Real (2002: 65). And so transgressing this taboo, while politically challenging, is PD's new frontier. It would mean extending participation to the economy by enabling greater social regulation of both the market and of the freedom of capital. And it would mean the establishment, for example, of worker management schemes, peasant co-operatives or community-run enterprises.

In a similar vein, there is a great deal of hypocrisy in advocating participation by the Other without looking at one's own institutional back yard. Often the bureaucratic structures and management processes that sanction PD schemes are themselves hierarchical (which only points up earlier arguments about PD as a vehicle for managerialism and disciplinarity). A participatory organisation would ostensibly reverse the flows of authority and knowledge. It would make management more accountable to its putative beneficiaries; and the resulting South-to-North and subaltern-to-elite flows would wean it into better learning from, as opposed to patronising, Third World and subaltern communities.

\section{Linking up with democratic politics}

A notable hindrance is PD's 'packageability': it is meant, as discussed earlier, to make participation adaptable to individualised projects rather than broader structural politics. It allows power to be managed by fetishising the 'inside' meeting space (ie acclaiming community 'togetherness', eulogising the facilitator), while ignoring the unmanageable 'outside' (the power of socioeconomic elites, the forces of globalisation, etc). This depoliticised approach to participation is what ensures that the latter centres not on empowering the Other, but on furthering our own complicities and desires. 
One way to break the stranglehold of complicity and desire is to link PD with broader democratic movements (cf Mohan \& Hickey, 2004; Kapoor, $2002 \mathrm{~b}$ ). This would involve building bridges between PD projects and wider local and transnational efforts for democratising state and market and politicising new spaces/issues (eg urban slums, sexual politics, biotechnology, water). But this would also mean having to give up on our desire for mastery and embrace long-term democratic struggles, with all the risks and setbacks that they entail (ie their success is never guaranteed).

\section{Hijacking participatory development}

That I have focused on the dangers of our complicities and desires does not mean that the 'beneficiaries' of PD are necessarily passive bystanders. As Glyn Williams points out, PD may 'indeed be a form of "subjection", [but] its consequences are not predetermined and its subjects are never completely controlled. . . [It may] open up new spaces for political action' (2004: 557). The reason is implicit in the above analysis: the disavowals, slips and contradictions (ie the Real) in PD-empowering the Other while protecting our own interests, desiring to appear benevolent while stage-managing community meetings, seeking consensus while ensuring it is single and smooth, facilitating open deliberation while exploiting panoptic constraint - make it unstable and susceptible. PD's hybridised script, in other words, is grounds for agency (cf Bhabha, 1994; Kapoor, 2003); its slippages render it vulnerable to re-interpretation, diversion, hijacking.

Much more work and research is required on this issue, but there is already evidence of the use of these types of political tactics: Jenkins \& Goetz (1999) document how participation inspires a right-to-information campaign challenging government corruption and accountability in Rajasthan; and Hildyard et al (2001; cf Williams, 2004: 569-570) speak of a PD project in which women participants, rather than using loans to buy dairy cattle, divert the funds for their own purposes (eg to recover family heirlooms used as loan equity). Moreover, what this means is that the three opportunities just discussed (publicising complicity and desire, extending participation to the economy and development decision making, linking up with democratic politics) do not depend only on us, ${ }^{8}$ but may be exploited by PD's subjects as well. The latter could conceivably shame us into facing up to our complicities, demand more transparent rules for deliberation and project management, or manipulate our need to look benevolent by cajoling us into providing more funding or better minority political representation.

This is not to announce the end of empire building through PD; but it is to say that even imperial power can be (and is) resisted and redeployed. Power, no matter whether it is hegemonic or authoritarian, is always hybridised (or haunted by the Real), making its triumphalism shaky and its victories temporary. Thus PD's gaze may well be constrictive, but there is nothing to prevent its subjects from returning a menacing glare or a mocking glance (Bhabha, 1994: 119), thereby inaugurating their agency. 


\section{Notes}

This article is based in part on an earlier work (2004a), in which I sketched but did not develop my arguments about self-implication and 'transference'. Thanks to my students and colleagues at the Faculty of Environmental Studies, and especially Leesa Fawcett, for their support and friendship; to Michael Bach for his insightful comments; and to Kent Murnaghan, as always.

1 There are undoubtedly several variants and hybrids of both institutional forms. But, in any case, part of my argument here is to problematise the differences between them: for, if complicity and desire are integral to each, then they are all equally 'engineered'. As a result, a claim that, say, the PRA approach is bottom-up, while the 'country ownership' approach is top-down, appears unconvincing. The same is true, in my view, of more politicised forms of participation such as Freirian pedagogy or Participatory Action Research: while perhaps more 'critical', they, too, depend on a convenor/facilitator, and hence are accompanied by the attendant complicities and desires.

2 I mention Mouffe because, like Žižek, she draws on Lacanian psychoanalytic theory to criticise liberal democracy. She is highly skeptical of 'consensus', taking Habermas to task over the notion (cf Mouffe, 2000).

3 This is Habermas's answer to the problem: he advocates an 'ideal speech situation', that is, a set of fair, inter-subjective rules and procedures governing public deliberation (cf Kapoor, 2002a).

4 Žižek is referring in this passage to 'postmodernism', but it applies well to PD.

5 I am inspired here by Hardt and Negri's historically specific definition of empire, which they distinguish from imperialism: 'Imperialism was really an extension of the sovereignty of the European nation-states beyond their own boundaries...In contrast to imperialism, Empire establishes no territorial center of power and does not rely on fixed boundaries or barriers. It is a decentered and deterritorializing apparatus of rule that progressively incorporates the entire global realm within its open, expanding frontiers' (2000: xii). On the relationship between participation and colonialism, see Cooke (2003). His genealogical analysis links Action Research to colonial forms of indirect rule.

6 I am twisting Arundhati Roy's line about democracy becoming a 'euphemism for neo-liberal capitalism' (2004: 56).

7 Although, as the next section argues, regarding them as pawns does not necessarily mean they will conform to our expectations.

8 I refer here to 'us' as change agents within academic or development institutions. It is, in many ways, these change agents to whom this article is primarily addressed. It is we who can exploit the institutional possibilities that I refer to in the first three sections above. If so, we may be able to take advantage of PD's instabilities and contradictions (perhaps in collaboration with PD's subjects). For example, we could push for our own institutions to face up to such contradictions and call for the extension and deepening of participation in decision making both 'inside' and 'outside' these institutions.

\section{References}

Bhabha, HK (1994) The Location of Culture (New York: Routledge).

Chambers, R (1994) Participatory Rural Appraisal (PRA): analysis of experience, World Development, 22 (9), pp 1253-1268.

Chambers, R (1997) Whose Reality Counts? Putting the First Last (London: Intermediate Technology Publications).

Cooke, B (2003) A new continuity with colonial administration: participation in development management, Third World Quarterly, 24 (1), pp 47-61.

Cooke, B \& Kothari, U (2001) The case for participation as tyranny, in: B Cooke \& U Kothari (eds), Participation: The New Tyranny?, pp 1-15 (London: Zed).

Ferguson, J (1990) The Anti-Politics Machine: Development, Depoliticization and Bureaucratic Power in Lesotho (Cambridge: Cambridge University Press).

Foucault, M (1984) The Foucault Reader, ed P Rainbow (New York: Pantheon).

Francis, P (2001) Participatory development and the World Bank, in: B Cooke \& U Kothari (eds), Participation: The New Tyranny? pp 72-87 (London: Zed).

Habermas, J (1976) Legitimation Crisis, trans T McCarthy (London; Heinemann).

Hart, M \& Negri, A (2000) Empire (Cambridge, MA: Harvard University Press).

Henkel, H \& Stirrat, R (2001) Participation as spiritual duty; empowerment as secular subjection, in: B Cooke \& U Kothari (eds), Participation: The New Tyranny?, pp 168-184 (London: Zed).

Hildyard, N, Hegde, P, Wolvenkamp, P \& Reddy, S (2001) Pluralism, participation and power: joint forest management in India, in: B Cooke \& U Kothari (eds), Participation: The New Tyranny?, pp 56-71 (London: Zed). 
Jenkins, R \& Goetz, A-M (1999) Accounts and accountability: theoretical implications of the right-toinformation movement in India, Third World Quarterly, 20 (3), pp 603-622.

Kapoor, I (2002a) The devil's in the theory: a critical assessment of Robert Chambers' work on participatory development, Third World Quarterly, 23 (1), pp 101-117.

Kapoor, I (2002b) Deliberative democracy or agonisitic pluralism? The relevance of the HabermasMouffe debate for Third World politics, Alternatives, 27 (4), pp 459-487.

Kapoor, I (2003) Acting in a tight spot: Homi Bhabha's postcolonial politics, New Political Science, 25 (4), pp $561-577$.

Kapoor, I (2004a) The power of participation, Current Issues in Comparative Education, 6 (2), pp 1-5, at http://www.tc.columbia.edu/cice/articles/ik162.htm, accessed 3 June 2005.

Kapoor, I (2004b) Hyper-self-reflexive development? Spivak on representing the Third World 'Other', Third World Quarterly, 25 (4), pp 627-647.

Kelsall, T \& Mercer, C (2003) Empowering people? World Vision and the 'transformatory development' in Tanzania, Review of African Political Economy, 96, pp 293-304.

Klein, M (2000) No Logo: Taking Aim at the Brand Bullies (Toronto: Vintage).

Kothari, R (1988) State against Democracy (Delhi: Ajanta Publications).

Makuwira, J (2004) Non-governmental organizations (NGOS) and participatory development in basic education in Malawi, Current Issues in Comparative Education, 6 (2), pp 1-11, at http:// www.tc.columbia.edu/cice/articles/jm162.htm, accessed 3 June 2005.

Mercer, C (2003) Performing partnership: civil society and the illusions of good governance in Tanzania, Political Geography, 22, pp 741-763.

Mohan, G \& Hickey, S (2004) Relocating participation within a radical politics of development: critical modernism and citizenship, in: S Hickey \& G Mohan (eds), Participation-From Tyranny to Transformation? Exploring New Approaches to Participation in Development, pp 159-174 (London: Zed).

Mohan, G \& Stokke, K (2000) Participatory development and empowerment: the dangers of localism, Third World Quarterly, 21 (2), pp 247-268.

Mosse, D (1994) Authority, gender and knowledge: theoretical reflections on the practice of Participatory Rural Appraisal, Development and Change, 25 (4), pp 497-526.

Mosse, D (2001) 'People's knowledge', participation and patronage: operations and representations in rural development, in: B Cooke \& U Kothari (eds), Participation: The New Tyranny?, pp 16-35 (London: Zed).

Mouffe, C (2000) The Democratic Paradox (London: Verso).

Parfitt, T (2004) The ambiguity of participation: a qualified defence of participatory development, Third World Quarterly, 25 (3), pp 537-556.

Parpart, J (2000) Rethinking participation, empowerment, and development from a gender perspective, in: J Freedman (ed), Transforming Development: Foreign Aid for a Changing World, pp 222-234 (Toronto: University of Toronto Press).

Renard, R \& Molenaers, N (2003a) Civil society participation in Rwanda's poverty reduction strategy, Discussion Paper, Institute of Development Policy and Management, University of Antwerp.

Renard, R \& Molenaers, N (2003b) The World Bank, participation and PRSP: the Bolivian case revisited, European Journal of Development Research, 15 (2), pp 133-161.

Roy, A (2004) An Ordinary Person's Guide to Empire (Cambridge, MA: South End Press).

Said, E (1978) Orientalism (New York: Pantheon).

Spivak, G (1988) Can the subaltern speak?, in: C Nelson \& L Grossberg (eds), Marxism and Interpretation of Culture, pp 271-313 (Chicago, IL: University of Illinois Press).

Spivak, G (1990) The Post Colonial Critic: Interviews, Strategies, Dialogues, ed S Harasym (New York: Routledge)

Srinivasan, L \& Narayan, D (1994) Participatory development tool kit: materials to facilitate community empowerment (Washington, DC: World Bank).

Williams, G (2004) Evaluating participatory development: tyranny, power and (re)politicisation, Third World Quarterly, 25 (3), pp 557-578.

World Bank (2000) PRSP Handbook (Washington, DC: World Bank).

World Bank (2003) The Heavily Indebted Poor Countries (HIPC) Debt Initiative: An OED Review (Washington, DC: World Bank).

Žižek, S (1989) The Sublime Object of Ideology (London: Verso).

Žižek, S (1997) The Plague of Fantasies (London: Verso).

Žižek, S (1999) The Žižek Reader, ed E Wright and E Wright (Oxford: Blackwell).

Žižek, S (2002) Welcome to the Desert of the Real! (London: Verso). 